\title{
PRESERVICE TEACHERS ON TEACHING WITH AND ABOUT ICT: AN INDONESIAN STUDY
}

\author{
Stefanus Christian Relmasira \\ Universitas Kristen Satya Wacana \\ Rose-Marie Thrupp \\ University of Sunshine Coast, Sippy Downs. \\ Stefanus.relmasira@staff.uksw.edu
}

\begin{abstract}
Teaching about and with digital technologies continues to challenge teachers. Aligned with the permeation of Information Communication Technologies (ICT) in our daily lives is the challenge of ICT in the classroom. Curriculum writers strive to identify declarative and procedural knowledge needed by future citizens. Teachers strive to design ICT-enabled learning that engages contemporary learners. The identity of a teacher of ICT and using ICT for learning challenges preservice teachers as they create their own identity in the classroom. These challenges cross borders, both geographical and cultural. Using a research approach developed by Hunt (2015), preservice teachers in a teacher education program in Central Java, Indonesia were asked to draw what teachers and ICT look like, sound like, and feel like. This study builds upon the ideas of Goodenough (1926) and Chambers (1983) to examine the views of teachers and ICT held by preservice teachers. These findings can inform the design of teacher education programs in supporting preservice teachers to build their self-efficacy as teachers teaching with and about ICT in their classroom and contribute to the construction of professional learning post-graduation.
\end{abstract}

Key words: ICT-enabled learning, pre-service teacher, teaching.

\section{INTRODUCTION}

Reflecting upon the identity of teachers who teach with and teach about Information Communication Technology (ICT) is an element of constructing professional identity as a contemporary teacher. Knowing deeply those attributes that contribute to being an effective teacher using ICT provides individuals with the basis for professional action and learning. Based in Indonesia, this study implements a method for reflection that is research-based and applicable in many educational contexts. In developing this method, Hunt (2015) elaborated upon earlier work by Goodenough (1926) and Chambers (1983) when he asked his Australian preservice teachers to draw a picture of what teaching with and about ICT looks like, sounds like, feels like, building upon the idea of Y-chart graphic organiser. This approach was considered culturally appropriate in the Indonesian context.

This study proffers findings about Indonesian preservice teachers' views of teachers teaching with and about Information Communication Technologies (ICT). The findings highlight both appropriate ideas and some misconceptions. Of particular importance is the lack of differentiation between ICT teachers and teachers using ICT for learning and teaching about ICT, perceptions of gender and requirements about intellectual ability. In identifying these issues, the study highlights thinking that has potential as a barrier to limit emergent teachers from using ICT for learning in their classrooms. Given the use of ICT by students away from school in Indonesia, it is essential for Indonesian teachers to see themselves as teachers who teach with and about ICT, thereby, motivating students because they see teachers as modern and up-to-date.

\section{LITERATURE REVIEW}


The focus of this study is twofold; firstly, the views of Indonesian preservice teachers and secondly, the method used to collect data. In the first instance, the method will be discussed to provide the context for the study.

The approach taken in this study draws upon notions of how researchers can view the thinking of others to gain insight into the views of others. Goodenough's (1926) Draw-a-Man, was used with children to provide insight into cognitive development. Chambers' (1983) Draw-a-Scientist has been used to engage university students with the elements of science and working scientifically. Thomas, Pederson and Finson (2001) built a Checklist (DASTT-C) based on Chambers's work identifying the attributes of a scientist. These researchers developed ways of making ideas visible in a way that reveals complexity: drawing.

Hunt (2015) sought to adopt this approach with preservice teachers in his university education courses by enabling preservice teachers to identify the attributes of teachers teaching with and about ICT. Hunt extended this thinking by combining drawing with the graphic organizer approach to thinking researched by Novak and Gowin (1984). Graphic organisers come in many shapes and sizes designed to support students to think in different ways for different purposes (e.g. Fishbone for cause and effect, concept mapping). The Y-chart approach is a graphic organizer shaped as a $\mathrm{Y}$ with each sector of the $\mathrm{Y}$ allocated to thinking about how an event or artifact sounds, feels, or looks. Hunt adapted this approach by combining drawing and words around sounds like, feels like and looks like. This frames the required thinking (and deeper cognitive engagement) being researched in a way that enables the participant to make meaning. Black (2015) suggests that visual representations document ways of knowing. This arts-based method enables meaning to be constructed. For the researcher, these "aesthetic responses" (Black, 2011) provide insight into knowledge and experiences.

This work originated as Hunt (2015) sought to understand how preservice teachers in his classes viewed themselves as teachers of and with ICT in their future professional work. Using these "aesthetic responses" (Black, 2011), Hunt had insight into the knowledge and experiences of preservice teachers to design workshops and tutorials accordingly, to challenge the current thinking held by them. Over four years, Hunt identified themes attributed of ICT teachers by these preservice teachers. These themes include Knowing the learner, collaboration, approaches to problem solving, classroom organization, connectedness and professional attributes of the teacher. He consequently developed a framework to analyse work by preservice teachers in education programs.

In the twenty-first century, preservice teachers during their university program are developing a view of teaching with and about ICT in their role in the future. They are making the shift from learning from ICT teachers and teachers using ICT to being teachers who teach with ICT and teach about ICT. Teacher educators are confronted with supporting students through this change, reshaping knowledge (Pajares, 1992) to a future orientation that results in effective teaching. This vocational self- efficacy builds upon perceptions of their ICT competencies in readiness for their future profession (Jamieson-Proctor, Finger \& Albion, 2010).

Mishra and Koehler (2008) suggest technology, pedagogy and content as components of knowledge that interact when teaching with ICT and subsequently, the knowledge that preservice teachers need. Alternately, Jamieson-Proctor, Finger and Albion (2010) suggest that this is accompanied by a vocational self-efficacy. A self-efficacy ready for this role builds upon perceptions of ICT competencies. Jamieson-Proctor, Finger and Albion suggest that technology, pedagogy and content interact with an emerging vocational self-efficacy when new teachers persist and work with ICT in the early years of teaching.

Much research has focussed on the elements of effective preparation of preservice teachers for their future role. Further, considerable research (e.g. Mishra \& Koehler, 2008) has focused on the 
declarative and procedural knowledge required by preservice teachers. However, few have identified the views of preservice teachers about the attributes and recognised the significance of these views in providing direction and opportunities to prepare teachers for future technological contexts.

The challenge of preparing future teachers is cross-cultural and no less in Indonesia where the uptake of ICT is extensive (Palekahelu \& Hunt, 2016). In their study of ICT use and access, they identified 77\% have access to a Smartphone across all ages from Year 4 to senior schooling. $79 \%$ use a computer at least once per week at home. However, the greater portion of this use is outside of the school. There is a vast challenge confronting the future teachers of Indonesia as they build selfefficacy in their work with students who already use ICT widely for self-directed learning, entertainment, and communication.

This study serves to answer Hunt's (2015) two questions in relation to preservice teachers in the context of an Education program in an Indonesian university in Salatiga Central Java, Universitas Satya Wacana:

1. What images do pre-service teachers hold of teachers who teach with and about iCT?

2. To what extent can the data available be used to design/develop a valid measure of perceptions about teachers as they prepare to teach with and about ICT?

\section{METHOD}

While some work has been carried out by surveys, this study uses drawing in association with a graphic organiser, a Y-chart, to provide an open context for preservice teacher thinking. Two classes of preservice teachers from the Christian University of Satya Wacana, Salatiga, Central Java participated in the study, forty-seven in all. In the second year of study in an education degree, they were asked to use the Y-chart graphic organiser model to draw and use pictures to show what a teacher using ICT looks, sounds and feels like, as well as showing the tools they use in their classes (Hunt, 2015).

\section{Table 1: Hunt's framework (2015)}

\section{Teaching practice}

Teaching practices

Collaboration

Approaches to problem solving

Classroom management

Knowing the learner

\section{Connectedness}

Connections: networks

Connections: across curriculum

\section{Attributes of the teacher}

Personal qualities

Appearance

Focus on language

Teacher-Student interaction

ICT Artifacts: these could be classified into ICT types

The artifacts noted could be classified as computers/tablets, audio/video devices, communication tools etc. 


\section{Data Analysis}

The first phase of the analysis involved drawing together words and phrases, which were reviewed for similarities. Images were analysed and included in the groupings. Within the similarities, groupings were made and category labels attached; thereby identifying attribute groupings. A moderator reviewed the categories.

In a second phase of the analysis, a comparison was completed against Hunt's framework. In the following analysis of the data, words and phrases were grouped and labeled to identify themes. These themes are now discussed in turn. Where data is used directly, it is italicized. In the first instance, a general description of the teacher teaching with and about ICT is provided and a collection of analogies presented to foreground the detailed analysis.

\section{General description of an ICT teacher}

Teachers who teach with and about are different from the others. They are dominantly viewed as cool, a term often used in context of this data related to up-to-date. The multi-talents of these teachers enable them to share and impact upon many people, maintaining student interest by being interesting and interested in the learning process.

The general view held by Indonesian preservice teachers of teachers who teach with and about ICT and do it well is revealed in these analogies:

Like milk, sweet and delicious, and like a stream flows always, pour the knowledge to the students

Like harmony just like a beautiful bird in the morning which gives the song beautiful and interesting

Like a plant when it is watered, it will be more beautiful and more expensive

Like an apple, delicious, beautiful and interesting

The concept of these teachers being fluent in teaching and being able to teach students new things is explored in the data analysis grouped according to professional and personal attributes. These themes were readily evident in the data. Professional attributes include knowledge of content, professional behaviours, and pedagogical attributes. Personal attributes include gender and personal presentation.

\section{Professional attributes}

\section{Knowledge of content}

A teacher who makes use of ICT is attributed with being a smart or wise person. The term genius was proffered once only. This was a strong theme in the data related generally to mastering content and knowing many things. In some instances, there were elaborations of smartness into the specific realm of ICT.

From a general perspective, the preservice teachers viewed these teachers as knowing everything, mastering little things and always providing new information. They have at their disposal many sources to find this information and look like Google or Internet in always being able to give information and knowledge to the students. 
In ICT-related content, teachers who teach with and about ICT were viewed as knowing about the development of technology and having many skills/competencies with ICT. They bring a laptop or a smartphone and always use the Internet, looking like they always follow the new technology. Further to this, they go everywhere with the laptop and cannot leave without the gadget. They demonstrate $a$ good mastery of ICT.

One person related attitudinal attributes to this person related to his/her content knowledge using terms such as living robot, never connects with other human, his/her close friend is gadget. This was supported by another phrase such as feels comfortable and safe in use of technology.

A few participants suggested that the teacher had to be an expert in ICT and experienced, relating smartness to currency of ICT content knowledge. A strong trend in the data was to use the term up-todate, for example, gadget is up-to-date and modern and modern technology. The term progressive in the data was grouped in this category. These teachers always has [have] innovation in the computer. They are global and know many things about development of current technology and they don't get left behind in various information. They are challenged to practise the computer.

\section{Professional behaviours}

Holding respect, being creative and demonstrating spirit and enthusiasm in their role is expected of ICT teachers. The term authority occurs with great frequency in the data. ICT teachers sound like they have authority, meaning they hold the respect of others for their leadership in teaching with ICT. They might even be charismatic.

ICT teachers need to demonstrate the ability to think, identified in terms of creativity and open-mindedness. Some usage of the term creative was visible on its own. Others expanded it in phrases: to be more creative, highly imaginative and encourage children to be creative and better. Associated with these views, the position of ICT teachers being open-minded, able to give solutions and able to act and think fast was expressed, though with limited frequency.

Furthermore, the ICT teacher is expected to have spirit to make us want to know and to have curiousity to learn. They need to enjoy teaching and feel good about delivering materials.

\section{Pedagogical attributes}

The teacher who teaches with and about ICT creates an environment in which students feel like they are being taught in a modern classroom. Use of sophisticated tools and media are evident in the classroom and these tools are up-to-date. Students are then comfortable to learn because modern people are open-minded.

These teachers bring an excitement into their classroom, providing motivation for the students and challenge [challenging] the students to do something. This perspective was often encapsulated in the term pump adrenaline. This involves making students want to practise continuously and trying again and by adding variations in teaching. The teaching and learning process is like beautiful music, it is simple and interesting, not complicated.

A further attribute includes being clear and wise in explaining. They are comfortable in giving advice and delivery of materials is very good and clear to understand. Communication needs to be professional and sophisticated. Intonations in voice are planned according to student needs to attract and motivate students; sounds like harmony that bring many useful knowledge. There are some references to the teacher making learning simple, pour[ing] the knowledge to the students. One participant suggested attributes such as mysterious and don't speak much, possibly reflecting on a past experience.

Preservice teachers indicated the need to make the situation comfortable. Warmth and responsibility is demonstrated through patience and being close to students. Learning is difficult but 
enjoyable, entertaining not monotone and gives satisfaction. Interactions need to be designed so they do not discriminate. Generally, teachers need to know teenagers well.

\section{Personal attributes}

Gender

Reference to gender in the data was evident with a trend toward teachers of both genders being. There was a strong use of he/she and himself/herself in responses. Fewer participants attributed maleness. Use of male-attributed adjective, handsome (ganteng) and macho indicated this to be so. In one case, the participant stated and teacher to be a man who has brilliant knowledge with three associated images all male in form. Other examples were experienced man, smart guy because he can hack other people's accounts, a man with a thousand dreams and man who masters content. Further interviews would need to be done to ascertain if this attribution was conscious, based on past experiences of the participant or related to the views of the future held by participants. Though few images of gender were provided, one small female image was the exception to male images.

Personal presentation

There are frequent references to presenting neatly while others suggested the need to be fashionable, though this occurred less frequently.

Some alternate views of teacher behaviours were expressed to a limited extent. These suggested serious, not friendly and don't care about people surroundings. They never connect with other humans.

\section{Comparison with Hunt's framework}

The data is now analysed using Hunt's framework. In a superficial analysis of the data, a reference to Hunt's (2015) scan of words and phrases enabled an identification of early similarities between Indonesian and Australian preservice teachers.

Table 2: A comparison of words/phrases used by Australian and Indonesian preservice teachers

\begin{tabular}{|c|c|}
\hline Australian preservice teachers 2011 & Indonesian preservice teachers 2016 \\
\hline $\begin{array}{l}\text { Nerdy, hacker, computer savvy, geek, } \\
\text { studious }\end{array}$ & \\
\hline Serious, boring, dull & $\begin{array}{l}\text { Serious, don't like people, Interesting, } \\
\text { enjoyable }\end{array}$ \\
\hline Highly organized, logical & Organised \\
\hline $\begin{array}{l}\text { Passionate, smart, intelligent, informed, } \\
\text { engaging }\end{array}$ & $\begin{array}{l}\text { Smart guy because he can hack other } \\
\text { people's accounts, has authority, highly } \\
\text { intelligent }\end{array}$ \\
\hline Unusual, awkward, Technology T-shirt & \\
\hline Creative, talented, imaginative, open-minded & $\begin{array}{l}\text { Creative, imagination, } \\
\text { innovate }\end{array}$ \\
\hline Modern, $21^{\text {st }}$ century & Up-to-date, cool \\
\hline Outgoing & \\
\hline Formal, formal clothes & $\begin{array}{l}\text { Neat, neat in dressing, fashionable, } \\
\text { interesting in his/her appearance, handsome }\end{array}$ \\
\hline Good attitude & Spirit \\
\hline & $\begin{array}{l}\text { Kind, polite, friendly } \\
\text { Pump adrenaline }\end{array}$ \\
\hline
\end{tabular}


Note: In the second column, italicized words indicate words that appeared with greatest frequency.

Use of Hunt's framework (2015) indicates strong differences in foci in the data. Hunt's Teaching practice can be associated with the Professional attributes category with some strongly evident differences. Connectedness is not evident in the data of this study. Attributes of a teacher connect strongly with personal attributes with some differences evident. The fourth criteria, ICT artifacts, was evident but was consumed in the analysis as professional attributes of being modern and up-to-date.

Table 3: Analysing data in Hunt's framework

\begin{tabular}{|c|c|}
\hline Hunt's framework (2015) & Categories from Indonesian data \\
\hline $\begin{array}{l}\text { Teaching practice } \\
\text { Teaching practices } \\
\text { Collaboration } \\
\text { Approaches to problem solving } \\
\text { Classroom management } \\
\text { Knowing the learner }\end{array}$ & $\begin{array}{l}\text { Professional attributes } \\
\text { Knowledge of Content } \\
\text { Professional behaviours } \\
\text { Creative } \\
\text { Authority (respected) } \\
\text { Spirit (motivational) } \\
\text { Pedagogical attributes } \\
\text { Modern } \\
\text { Excitement, motivation, } \\
\text { challenge } \\
\text { Communication } \\
\text { students } \\
\text { Interaction with students }\end{array}$ \\
\hline $\begin{array}{l}\text { Connectedness } \\
\qquad \text { Connections: networks } \\
\text { Connections: across curriculum }\end{array}$ & $\begin{array}{l}\text { No references to this category were evident } \\
\text { in the data for this study. }\end{array}$ \\
\hline $\begin{array}{l}\text { Attributes of the teacher } \\
\qquad \begin{array}{l}\text { Personal qualities } \\
\text { Appearance } \\
\text { Focus on language } \\
\text { Teacher-Student interaction }\end{array}\end{array}$ & $\begin{array}{l}\text { Personal attributes } \\
\text { Gender } \\
\text { Appearance } \\
\text { Personal qualities }\end{array}$ \\
\hline ICT artifacts & $\begin{array}{l}\text { Limited references to specific artifacts } \\
\text { smartphone, laptop and Internet. Other } \\
\text { references were limited to up-to-date. }\end{array}$ \\
\hline
\end{tabular}

In summary, there were some strong similarities aligning the Indonesian data and the framework developed with Australian preservice teachers. Equally strong are the differences. The data in this study placed a heavy emphasis on knowledge of content and specifically stated that the knowledge and processes be up-to-date and modern. Teachers need to be different, following new technology, thinking and acting differently in the classroom in interactions that motivate students. Some recognition was given to the teacher being creative and giving solutions, which relates to Hunt's (2015) 'Approaches to problem-solving'. Far less emphasis was placed on knowing the learner and no attention was given to classroom management or collaboration.

In this study, some behaviours labeled as pedagogical attributes strongly relate to Hunt's teaching practices. These include motivation, maintaining student attention, and making students feel comfortable, not overburdening students, giving students material. 
Personal qualities are recognized in both contexts. Views on the gender of the teachers from this study need further investigation. There was insufficient clarity around the potential of females to use teach with ICT. Given that the self-efficacy of a teacher develops from beliefs (Jamieson-Proctor, Finger \& Albion, 2010; Pajares, 1993), there may be issues that being an ICT teacher or teaching with ICT is not considered a role for females. Given the majority of teachers are females, there could be repercussions for the future use of ICT in classrooms. There was no focus on connectedness and little focus on ICT artifacts specifically in this study.

\section{DISCUSSION}

The relevance of these findings cannot be understated for the Indonesian context. Given the current use of ICT in Indonesia and particularly, in Salatiga, the site of the study, the competencies of ICT teachers and teachers using ICT and teaching about ICT are relevant to schools in the immediate and distant future if they are to respond to the culture of learners. Current data (Palekahelu, Thrupp \& Hunt, 2016) indicates high access and usage of ICT by students beyond the school, especially with mobile phones. Indonesian students are arriving at school with knowledge of the benefits of ICT for learning, communication and entertainment (Relmasira, Thrupp \& Hunt, 2016). Future teachers require preparation to interact with ICT-enabled learning to meet the needs of these students.

In relating these findings to Hunt's research questions, this study endeavours to provide a view of teachers teaching with and about ICT as proposed by Indonesian preservice teachers. In so doing, it is posited that this work gives cause for reflection on the self-efficacy of future teachers and the use of ICT in their classrooms by the institutions preparing them for their future roles. Three major issues are conspicuous from this study in considering the development of self-efficacy as a teacher in relation to the use of ICT.

Firstly, there is some indication that these preservice elementary teachers are not yet able to differentiate between between being an ICT teacher and a teacher who uses ICT for learning in their classroom. The ICT teacher who teaches solely about ICT including programming is a different teacher from the elementary school teacher who teaches with and about ICT to younger children. It is possible that these students cannot yet discriminate between these roles, indicating this as a strong teaching point in their undergraduate study.

Secondly, this study proffers that preservice teachers view general teachers who need to use ICT for teaching and teach about ICT as needing to be wise and charismatic. The question that comes to mind is: are these preservice teachers setting standards too high for themselves? In a future where all teachers need to be teaching with and about ICT, are all the attributes identified required by all teachers to be effective in the use of ICT in elementary classrooms? While the compilation of attributes provides a composite image, it is to be considered if the list is aspirational or a requirement

Thirdly, it is to be questioned that these preservice teachers are reacting to the style of teaching with which they are familiar in their education, most having come into university from the Year 12 equivalent. A traditional textbook approach and total direct teaching approach remains the pedagogical stance in some aspects of Indonesian education. The strong themes in learning being comfortable and interesting through ICT may respond to their own pedagogical experiences in schools. These preservice students as teachers may struggle to implement comfortable and interesting, not having experienced it themselves; another strong teaching point in their undergraduate study.

\section{What images do pre-service teachers hold of teachers who teach with and about ICT?}


Teachers teaching with and about ICT are knowledgeable in the area of ICT and different from other teachers. Though differences from other teachers are not specifically elaborated, the data suggest that these teachers are different by being modern and up-to-date in their knowledge and practices related to ICT and are easily identifiable by these attributes. They will own or have access to ICT but images related to specific practices with ICT are not evident.

Generally, ICT teachers are smart and neatly dressed. Their interactions with students are confident and sure. Their teaching is enjoyable and interesting and motivates students to keep learning. They create a comfortable space for learning.

\section{To what extent can the data available be used to design/develop a valid measure of perceptions about ICT Teachers?}

The data from the students creates a composite image of the teacher teaching with and about ICT when condensed. Most participants provided a complete image of an ICT teacher from their perspective including professional and personal attributes. A few, however, limited their responses which did not present a clear image, for example, one participant gave three words only, kind, smart, happy.

An interesting aspect of the data for this study is the frequent use of analogies. Though Hunt (2015) found Australian students very ready to use images and drawings, this was less so with Indonesian participants. Indonesian students were less likely to use images though drawing was evident on a limited basis. However, analogies were evident creating images through words. It could be posited that this is due to the cultural differences of the preservice teachers, prior educational experiences or the differences in the Education programs of the Institutions. Further investigation would contribute to the efficacy of this methodology as a cross-cultural approach. In future studies of this kind, at least, initially, a follow-up stimulated recall methodology could support enhanced validity.

\section{Conclusion}

This study has two offerings for teachers and schools. Firstly, the findings of this study in establishing a composite image of teachers working with ICT can be used on multiple levels to achieve various outcomes for teachers, schools and education systems. Secondly, the method used, Y chart and Hunt's framework (2015), can be used to work with teachers to support them as they reflect upon meeting the challenge of teaching with and about ICT in their classrooms.

Understanding how preservice teachers view the identity of teachers who teach with and about ICT provides key points for consideration by faculties of Education designing and modifying programs to prepare teachers for their future role. Through knowing how and why future teachers view the use of ICT in classrooms, courses can be designed to mentor preservice teachers to overcome misconceptions, particularly those in relation to gender and level of intellectual ability. The composite image and standards in this study could be considered aspirational and hence, daunting for an emergent teacher challenged by the chaos that is teaching (Mishra \& Koehler, 2008).

This information is also of use to schools as they welcome new teachers and design ongoing professional development to build strong effective teachers, teaching with and about ICT. The study suggests that some emergent teachers may feel inadequate with regard to ICT due to their gender, lack of ownership of ICT artifacts and their intellectual ability. These perceptions need attention to help emergent teachers design a pathway of development toward an appropriate self-efficacy for an effective teaching role in contemporary schools.

Individual educators can use this approach and the framework to reflect upon the attributes they demonstrate as they meet the challenge of teaching with and about ICT. Comparing one's 
attributes with a framework compiled by others provides a reflective practice to build a pathway of future learning. Furthermore, use of the method used in this study, by a school in comparison with guidelines from the system could enable the compilation of school directions for professional learning.

For those working with teachers of the future regardless of cultural background, the approach taken in this study is a useful means of gaining insight into views and perceptions. What if all teachers of the future left their undergraduate study already on a journey of understanding themselves as teachers who teach with and about ICT?

\section{REFERENCES}

Black, A. (2011). Forming knowledge with new shapes: what arts-based research methods can offer Rockhampton: CQUniversity.

Black, A. \& Odea, S. (2015). Building a tapestry of knowledge in the spaces in between: weaving personal and collective meaning through arts-based research. In Trimmer, K, Black, A. L., Riddle, S. (eds). Mainstreams, Margins and the Spaces In-Between: New possibilities for education research. Routledge. pp.13-35

Chambers, D. W. (1983). Stereotypic images of the scientist: The Draw a Scientist Test. Science Education, 67 (2), 255-265.

Goodenough, F. L. (1926). Measurement of intelligence by drawings. New York: Harcourt Brace.

Goodman, J. (1988). Constructing a practical philosophy of teaching: A study of pre-service teachers' professional perspectives. Teaching and Teacher Education, 4, 121-137.

Hunt, J. (2015). Pre-Service Teacher Perceptions Of ICT Teachers. Proceedings of ICICTE 2015, Kos, Greece.

Jamieson-Proctor, R., Finger, G., \& Albion, P. (2010). Auditing the ICT Vocational Self-Efficacy of Teacher Education Undergraduates. Presentation at the International Society for Technology in Education (ISTE) Conference, Denver Colorado, June 27-30, 2010.

Mishra, P. \& Koehler, M. (2008). Introducing Technological Pedagogical Content Knowledge. Paper presented at the Annual Meeting of the American Educational Research Association New York City, March 24-28, 2008. Reviewed on 21 January, 2016 at http://punya.educ.msu.edu/ presentations/AERA2008/MishraKoehler_AERA2008.pdf

Novak, J. \& Gowin, B. (1984). Learning how to learn. Cambridge University Press.

Pajares, M. F. (1992). Teachers' beliefs and educational research: Cleaning up a messy construct. Review of Educational Research, 62 (3), 307-332.

Pakehelu, D. \& Hunt, J. (2016). ICT use by schools in Kota Salatiga, Central Java. Unpublished paper.

Thomas, J. A., Pederson, J. E., \& Finson, K. (2001). Validating the Draw-a-science teacher test checklist (DASTT-C): Exploring mental models and teacher beliefs. Journal of Science Teacher Education, 12 (3), 295-310. 